\title{
20th Century quest for new art and interdisciplinary approach
}

Sezer Cihaner Keser*

Suggested Citation:

Education. 7

Abstract 
1. Introduction

2. Art Education and Interdisciplinary 
Global Journal of Arts Education. 7 
3. Results 


\section{References}

Learning in and through art: a guide to discipline based art education

A history of art education

Weimar devlet yapievi

\section{Yasadikca Egitim, 54}

Anadolu Universitesi Egitim Fakültesi Dergisi, 2,

Sanat sözlügü

Ogretmen Dunyası, 49 